\title{
Short Run Impact of Public Finance on Inflation Rate in Ethiopia; Empirical Evidence with Time Series Analysis (1974/75-2018/19)
}

\author{
Endashaw Sisay Sirah \\ MSc, Economics Department, Mizan Tepi University, Mizan-Aman, Ethiopia
}

\begin{abstract}
According to various schools of economic thought there are many source of inflation. Nonetheless the source of it in each country may not be a source of inflation for other countries. Even if detecting the influence of public finance on inflation rate is the main concern to both developing and developed nations for their economic policy. As the recorded statistics implied that the Ethiopian government has high budget deficit, external debt, and high government expenditure and low tax revenue. For that reason the main objective of the present study was to test the impact of external debt, government expenditure, government budget deficit and tax revenue on inflation rate in Ethiopia by using annual time series data which run from 1974/75 to 2018/19. The researcher used ADF unit root test, PP-unit root test, short run ARDL model and diagnostic test. The study result inferred that there is no variable which become stationary at second difference which means the listed variables are stationary al level and first difference. The short run ARDL model verified budget deficit and government expenditure has positive impact, but tax revenue and external debt has negative impact on Ethiopian inflation rate. All diagnostic tests showed there is no problem on short run model. Based on the study result it is better to focus on minimizing government expenditure and increasing government revenue.
\end{abstract}

Keywords: Ethiopia, Inflation Rate, Public Finance, Short Run Impact

DOI: $10.7176 / \mathrm{JESD} / 11-9-06$

Publication date:May $31^{\text {st }} 2020$

\section{Introduction}

Still a number of economists delineate inflation in dissimilar means; but there is one common agreement. With the common sense, inflation means a sustainable rise of all goods and services price. According to various schools of thought there are many source of inflation. But the source of inflation in a given country may not be a source of inflation for other countries. It could be the dissimilarities found in the mastery, sources, time and in their principal economic circumstances. Moreover, there economic status like being developing and developed nations of the world see to witness rise or decrease in price. Before 10 years and currently Ethiopia take a shower of inflationary occurrence, parallel a government takes action to control the problem (Gylych \& Abdurahman, 2016).

According to (Yismaw, 2019) "Inflation is started together a momentum in the late 2005 and early 2006 few months after the national election of the country. General prices rose by more than 44 percent on average and food price inflation reached 60 percent in 2008. Although the picture is relatively less pronounced, non-food price has also been rising over the same period. Although general inflation slowed down to $9 \%$ annual growth in 2009 and 2010 the figures remained at high level in 2011 steadily increasing to reach average annual rate of 28.1 percent. Despite efforts by monetary authorities, the average rates remained above the target levels in 2012. This shows that inflation has become the most important macroeconomic problem of the Ethiopian economy in recent years. One salient feature of the recent inflationary pressure in Ethiopia is that it is led by food inflation".

Just like several developed and developing countries, in Ethiopia one of the incredible macroeconomic objectives is to improving the living standard of peoples with moderate inflation. Though, there has been substantial argument on the condition of the inflation and economic growth correlation. In the late 1970s and at the beginning of 1980s, various nations, comprising the United States, practiced great inflation. A comprehensive agreement arose that this routine was undesirable, and monetary officials all over the world agreed policies intended to reduce high inflation. If inflation is painfully high, policymakers distinguished what track they desirable to down inflation even though they were indeterminate of its final terminus. Inflationary delinquent has become the greatest significant macroeconomic tricky of the Ethiopian economy in current existences (Denbel, Ayen, \& Regasa, 2016).

The subject of inflation has been a problem of disquiet in place of economists, eventually as it leftovers a statement that the factual earnings of nations are negatively influence through inflation if the government cannot address the problem by using funding. If there is low productivity, this funding may create another economic problem like inflation inclination in the economy. The reason for this is also due to low purchasing power of money. Therefore this empirical study objective is to see the impact of public finance on inflation rate.

According to Keynes (1936) and his followers postulate that the rise of aggregate demand is due to demand pull inflation, i.e. where the supply of goods and services in to the economy less than from aggregate demand of the economy. In this case the aggregate demand is a function of consumption (C), investment (I) and government expenditure (GE). In 1950s and 1970s the known theory known as inflation cost push theory; it is also called new 
inflation. This is result from the increase of wage or increase the price of inputs, which leads the rise of cost of production.

Another theory of inflation stated that more demand or less demand, supply decrease and supply increase, this considered as economic structure factors, which more formally known as structural inflation theory. If there is structural enhancement, it takes along a fast economic growth, moreover, when developing countries try to change their undeveloped structure, those countries can find them as they are free from inflationary problem. Conferring to (Totonchi , 2011), the anti-inflationary measure could take just like reduce monetary policy expansion. In many cases "contradiction as such policies prescriptions end up stagnating the economic growth of the less developed economies".

In 1970's the idea of rational expectation became a dominant one, which also considered as macroeconomic revolution, (Lucas, 1972; McCallum, 1987). The main assumption of rational expectation mainly focused on households, firms and government should form their macroeconomic expectation rationally depend on current and past relevant information. A New neo-classical synthesis of inflation; explained that a monetary and demand factors a major determinants of economic business cycles.

\section{Methodology of the Study}

\subsection{Data Source of Variables}

Table 1: The Main Source of Data

\begin{tabular}{|l|l|l|l|l|}
\hline Short form of Variables & Long form of variables & Unit & Time & Data Source \\
\hline BD & Budget deficit & \% of GDP & $1974 / 75-2018 / 19$ & WDI and NBE \\
\hline ED & External debt & \% of GDP & $1974 / 75-2018 / 19$ & WDI and NBE \\
\hline INFR & Inflation Rate & Percentage & $1974 / 75-2018 / 19$ & WDI and NBE \\
\hline GE & Government Expenditure & percentage & $1974 / 75-2018 / 19$ & WDI and NBE \\
\hline TR & \% of GDP & $1974 / 75-2018 / 19$ & WDI and NBE \\
\hline \multicolumn{4}{|l}{ Tax revenue } & \multicolumn{3}{|c}{ Note: WDI is World Development Index, NBE is National Bank of Ethiopia } \\
\hline
\end{tabular}

\subsection{Specification of Model}

The quantity theory of money, inflation monetary theory, modern quantity theory of money and inflation, inflation cost push theory, structural inflation theory, a new neo-classical synthesis of inflation, neo political macroeconomics of inflation and Phillips curve explanation has been used as a guideline to develop a model. (Phillips, 1958; Sisay, 2020a; Sisay, 2020b; Ayalew, 2000) maintained the empirical arrangement as follows;

$\mathrm{INF}=\mathrm{f}(\mathrm{UNR})$.

Though, once valued the importance of other factors in explaining inflation rate, the model is stated as below.

$\mathrm{INFR}=\mathrm{f}(\mathrm{BD}, \mathrm{ED}, \mathrm{GE}, \mathrm{TR})$

Where $\mathrm{F}$ is a function of and all other variables are explained with table 1 . Moreover, the above functional form has the following econometric form ( Sisay, 2020b):

INFR $_{\mathrm{t}}=\beta_{0}+\beta_{1} \mathrm{BD}_{\mathrm{t}}+\beta_{2} \mathrm{ED}_{\mathrm{t}}+\beta_{3} \mathrm{GE}_{\mathrm{t}}+\beta_{4} \mathrm{TR}_{\mathrm{t}}+\mathrm{e}$.

\subsection{Unit Root Test with Drift}

$$
\Delta X_{t}=\alpha_{0}+\gamma X_{t-1}+\sum_{i=1}^{p} \beta_{i} \Delta X+e_{t}
$$

Where: $\Delta$ is difference operator, $\alpha_{0}$ is drift term, $\mathrm{P}$ is the lag order of $\mathrm{X}, \mathrm{t}=$ time subscribe, $\beta_{i}=$ is a measure of lag length, $\gamma=\delta-1$ the coefficient of $X_{t-1}$ which measures the unit root, e is the white noise, $\Delta X_{t}$ is $X_{t}-X_{t-1}$ which means the first difference of $X_{t}, X_{t-1}$ is lagged values of order one of $X_{t}$. Formally we want to test the null hypothesis: $\mathrm{H}_{0}: \gamma=0$, against the one-sided alternative $\mathrm{H}_{1}: \gamma<0$ (Dickey \& Fuller, 1979). Then if t-statistics is greater than $\mathrm{ADF}$ critical value, the null hypothesis will reject i.e. the established variables are stationary (Sisay \& shah, 2020).

The general ARDL model for this study is appears as follows (Pesaran, Shine , \& Smith , 2001):

$D\left(\operatorname{Ln}\left(I N F R_{t}\right)\right)=\beta_{1}+\alpha_{11} \operatorname{Ln}\left(I N F R_{t-1}\right)+\alpha_{21} \operatorname{Ln}\left(E D_{t-1}\right)+\alpha_{31} \operatorname{Ln}\left(B D_{t-1}\right)+\alpha_{41} \operatorname{Ln}\left(G E_{t-1}\right)+$

$\alpha_{51} \operatorname{Ln}\left(T R_{t-1}\right)+\sum_{i=1}^{p} \theta_{1 i} D\left(\operatorname{Ln}\left(I N F R_{t-i}\right)\right)+\sum_{i=1}^{q} \theta_{2 i} D\left(\operatorname{Ln}\left(E D_{t-i}\right)\right)+\sum_{i=1}^{q} \theta_{3 i} D\left(\operatorname{Ln}\left(B D_{t-i}\right)\right)+$

$\sum_{i=1}^{q} \theta_{4 i} D\left(\operatorname{Ln}\left(G E_{t-i}\right)\right)+\sum_{i=1}^{q} \theta_{5 i} D\left(\operatorname{Ln}\left(T R_{t-i}\right)\right)+\varepsilon_{1 i}$

To see the short run relationship between inflation rate and public finance the researcher defined the error correction term $\left(\mathrm{ECM}_{\mathrm{t}-1}\right)$ just as follows (Sisay, 2019; Sisay, 2020).

$\mathrm{ECT}_{\mathrm{t}-1}=\operatorname{Ln}\left(\operatorname{INFR}_{\mathrm{t}-\mathrm{i}}\right)-\left[\theta_{0}+\sum_{\mathrm{i}=1}^{\mathrm{q}} \theta_{1 \mathrm{i}}\left(\operatorname{Ln}\left(\operatorname{INFR}_{\mathrm{t}-\mathrm{i}}\right)\right)+\sum_{\mathrm{i}=1}^{\mathrm{q}} \theta_{2 \mathrm{i}}\left(\operatorname{Ln}\left(\mathrm{ED}_{\mathrm{t}-\mathrm{i}}\right)\right)+\sum_{\mathrm{i}=1}^{\mathrm{q}} \theta_{3 \mathrm{i}}\left(\operatorname{Ln}\left(\mathrm{BD}_{\mathrm{t}-\mathrm{i}}\right)\right)+\right.$ $\sum_{\mathrm{i}=1}^{\mathrm{q}} \theta_{4 \mathrm{i}}\left(\operatorname{Ln}\left(\mathrm{GE}_{\mathrm{t}-\mathrm{i}}\right)\right)+\sum_{\mathrm{i}=1}^{\mathrm{q}} \theta_{1 \mathrm{i}}\left(\operatorname{Ln}\left(\mathrm{TR}_{\mathrm{t}-\mathrm{i}}\right)\right)$ 
3. Result of the Study

3.1. Unit Root Test

Table 2: Stationarity Test Result of Variables

\begin{tabular}{|c|c|c|c|c|c|c|c|}
\hline \multirow[t]{2}{*}{ Variables } & \multirow[t]{2}{*}{ t-statistics } & \multirow[t]{2}{*}{ ADF-value } & \multirow{2}{*}{$\begin{array}{l}\text { Lag } \\
\text { (AIC) }\end{array}$} & \multirow[t]{2}{*}{ PP-value } & \multirow{2}{*}{$\begin{array}{ll}\text { Adj. } & \text { t- } \\
\text { Statistics }\end{array}$} & \multicolumn{2}{|c|}{ Stationary } \\
\hline & & & & & & $\mathrm{ADF}$ & $\mathrm{PP}$ \\
\hline LNDEBT & 4.350873 & $2.931404(5 \%)$ & 2 & $2.931404(5 \%)$ & 4.357069 & $\mathrm{I}(1)^{*}$ & $\mathrm{I}(1)^{*}$ \\
\hline LNDEF & 3.369215 & $2.929734(5 \%)$ & 2 & $2.929734(5 \%)$ & 3.329739 & $\mathrm{I}(0)^{*}$ & $\mathrm{I}(0)^{*}$ \\
\hline LNINF & 4.159796 & $2.941145(5 \%)$ & 2 & $2.929734(5 \%)$ & 8.338355 & $\mathrm{I}(0)^{*}$ & $\mathrm{I}(0)^{*}$ \\
\hline LNGEX & 3.071487 & $2.931404(5 \%)$ & 2 & $2.931404(5 \%)$ & 5.583944 & $\mathrm{I}(0)^{*}$ & $\mathrm{I}(0)^{*}$ \\
\hline LNTR & 7.107228 & $2.931404(5 \%)$ & 1 & $2.929734(5 \%)$ & 3.047256 & $\mathrm{I}(1)^{*}$ & $\mathrm{I}(0)^{*}$ \\
\hline
\end{tabular}

Note:- AIC is Akaike Information Criteria, 5\% Indicates Significance Level, PP-Phillips-Perron test statistic and ADF-Augmented Dickey-Fuller test statistic

Source: Author Based on E views-v-10

MacKinnon (1996) with constant, no trend, (5\%) indicates at 5\% level of significance, I (0) and I (1) stationary of the listed variables at level and first difference. Null Hypothesis: Each variable has a unit root at level and first difference. * Indicates rejection of the null hypotheses at $5 \%$ level of significant in level and first difference. From the above table the researcher conclude that according to ADF external debt and tax revenues are stationary at first difference and other variables are stationary at level. But according to PP test all variables are stationary at level except external debt.

\subsection{ARDL Error Correction Regression}

Table 3: Short Run Relationship of Variables

\begin{tabular}{crrrr}
\hline \hline \multicolumn{5}{c}{ D(LNINFR) is Dependent Variable } \\
\hline \hline Variables & Coefficient & Std. Error & t-Statistic & Prob. \\
\hline \hline C & -9.150530 & 1.116902 & -8.192777 & 0.0000 \\
D(LNINF(-1)) & 0.333035 & 0.127949 & 2.602869 & 0.0144 \\
D(LDEFI) & 2.673023 & 1.149518 & 2.325342 & 0.0273 \\
D(LDEFI(-1)) & 4.096499 & 1.291672 & 3.171469 & 0.0036 \\
D(LEXP) & 14.97026 & 5.076051 & 2.949193 & 0.0062 \\
D(LEXP(-1)) & 12.76234 & 5.292917 & 2.411211 & 0.0225 \\
D(LTR) & -18.11255 & 3.698661 & -4.897055 & 0.0000 \\
D(LTR(-1)) & -11.01167 & 3.817145 & -2.884791 & 0.0073 \\
D(LDEBT) & -3.969198 & 2.033087 & -1.952301 & 0.0606 \\
Speed of Adjustment & -1.757494 & 0.210644 & -8.343419 & 0.0000 \\
\hline \hline R-squared & $\mathbf{0 . 8 3 6 4 0 3}$ & Adjusted R-squared & $\mathbf{0 . 7 9 1 7 8 6}$ \\
\hline \hline
\end{tabular}

Source: Author Based on E views-v-10

The above table indicates as there is positive relationship between budget deficit, government expenditure and inflation rate. Oppositely there is also negative relationship between tax revenue, external debt and inflation rate in Ethiopia. Other things remaining constant, when the current and lag budget deficit increased by one unit inflation rate increased by $267 \%$ and $407 \%$ respectively, this is highly acceptable at $1 \%$ and $5 \%$ level of significant. Similarly, when the current and lag government expenditure increased by a unit inflation rate also increased by $1497 \%$ and $1276 \%$ respectively. This output also highly significant at $1 \%$ and $5 \%$. This specific result is as expected and support economic hypothesizes. If there is high government expenditure this produce the problem of budget deficit and high inflation rate by creating high job opportunity. This output akin the study of (Cosimo , 2011).

Contrarily, when the current and lag tax revenue increased by one percent inflation rate reduced by $1811 \%$ and $1101 \%$. This may be happen when the government increased tax to get more revenuer. Moreover external debt found to be highly important to explain inflation rate i.e. when this variable increased by $1 \%$ inflation rate decreased by $40 \%$. This is also significant at $10 \%$. This outcome indicates the government may use part of external income to control inflation rate in Ethiopia. Lastly, the included independent variables explained the dependent variable by $84 \%$. 


\subsection{Testing the ARDL Model Validity}

Several diagnostic tests are performed in order to safeguard that all the models are reliable. So, the specified model passes all suggested applicability tests. Like Normality test, Breusch-Godfrey Serial Correlation LM test, Heteroskedasticity test, Breusch-Pagan-Godfrey, Ramsey RESET test and CUSUM test has not been futile.

\section{Conclusion and Recommendation}

This study examined the short run impact of public finance (external debt, budget deficit, government expenditure, and tax revenue on inflation rate by using time series date which run from 1974/75 to 2018/19. All listed variables are subjected for both ADF and PP unit root tests, the result of this unit root test implied as there is $\mathrm{I}(0)$ and I(1). The ARDL short run model was employed to see the impact of public finance on inflation rate. Besides, the considered model also passed the major diagnostic tests. The short run model implied all independent variables have high impact on inflation rate. So, based on the study result it is better to focus on minimizing government expenditure and increasing government revenue.

\section{References}

Ayalew, Y. (2000). The Trade off between Inflation and unemployment in Ethiopia. Proccedings of the 10th Annual Conference on the Ethiopian Economy. Nazret: Ethipia Economic Association.

Cosimo, M. (2011). The nexus between public expenditure and inflation in the Mediterranean countries. Online at https://mpra.ub.uni-muenchen.de/28493/MPRA Paper No. 28493, posted 29 Jan 2011 19:59 UTC

Denbel, F. S., Ayen, Y. W., \& Regasa, T. A. (2016). The Relationship between Inflation, Money Supply and Economic Growth in Ethiopia: Co integration and Causality Analysis. International Journal of Scientific and Research Publications, 6(1).

Dickey, A. D., \& Fuller, A. W. (1979). Distribution of the estimators for autoregressive time series with a unit root. Journal of American Statistical Association, 74, pp. 427-431.

Gylych, J., \& Abdurahman, I. (2016). he Impact of Inflation On Unemployment in Nigeria (2001-2013). Sacha Journal of Policy And Strategic Studies, 6(1), 28-34.

Keynes , J. M. (1936). The general theory of employment, interest and money. London: Macmillan publication.

Lucas , R. E. (1972). Expectation and the neutrality of money. J. Econ Theory, 4, 103-124.

McCallum, B. (1987). Inflation: Theory and Evidence. New York. The American National Bureau of Economic Working Paper No. 2312

Pesaran, H. M., Shine , Y., \& Smith , R. J. (2001). Bounds testing approaches to the analysis of level relationships. Journal of Applied Econometrics, 16 (3), 289-32.

Phillips, A. (1958). The Relationship between Unemplyment the rate of change of Many Wage Rates in the United Kingdom, 1861-1957 . Economica, pp.283-299.

Sisay, E. (2019). Causality of Unemployment and Macroeconomics in Ethiopia. Global Journal of Economics and Business Adiministration, volume 4(24).

Sisay, E. (2020a). Macroeconomic Determinants of Unemployment in Ethiopia. Global Scientific Journal, 8(02), $4718-4729$.

Sisay , E. (2020b). The Existence of Phillips Curve theory in Ethiopia; Depend on Augmented Phillips curve theory Analysis. American Journal of Design, 2(6), pp.1-10.

Sisay, E., \& shah, S. A. (2020, February). The Correlation Between Real Growth Domestic Product And Unemployment In Ethiopia . International Journal of Current Research, 12(02), pp.10213-10218.

Totonchi, J. (2011). Macroeconomic theories of inflation. Int. Conf. Econ. Finan, 4, 459-462.

Yismaw, T. G. (2019). Effect of Inflation on Economic Growth of Ethiopia. Journal of Investment and Management, 8(2), 48-52. 